\title{
Myths and beliefs of long-term care providers towards starting inhaled medications in children with bronchial asthma
}

\author{
*N A W K Nettikumara ${ }^{1}$, K A M K U N Malaviarachchi ${ }^{2}$, Y C N Dissanayaka ${ }^{3}$, U P P C Gunarathna ${ }^{4}$, S \\ M S Wijesundara ${ }^{4}$, W P D H Wanasundara ${ }^{4}$
}

Sri Lanka Journal of Child Health, 2015; 44(4): 202-208

\begin{abstract}
Introduction: Management of persistent forms of asthma needs long term use of inhalers. Myths and beliefs of long term care providers influence compliance with inhaled medications.

Objective: To assess the presence of myths and beliefs of long term care providers towards starting inhaled medications in children with bronchial asthma and the influence of socio-demographic factors on them.
\end{abstract}

Method: A prospective cross-sectional descriptive study was carried out in clinics and in-ward patients of paediatric units at 3 Base Hospitals using a self-administered questionnaire. The patients selected were those who were newly planned to start or those already on inhaled medications for bronchial asthma. Care providers who were educated by our team and short term care givers were excluded.

Results: The study included 242 long term caregivers of children with bronchial asthma. Of them, $98 \%$ had education beyond Grade 5 and $75 \%$ had a family income greater than Rs.30, 000/- per month. Majority (59.4\%) were already informed regarding the use of inhalers and of them, more than $95 \%$ received it from a health care worker. The most prevalent myth among them was that 'the cost of inhalers is very high' $(n=99,41 \%)$. Among the other myths, a significant percentage of parents believed that 'inhalers may damage the lungs' $(n=92,38 \%)$ and in 'inhaler dependency' $(n=86$, $35.5 \%$ ). The proportions of parents having myths

\footnotetext{
${ }^{1}$ Acting Consultant Paediatrician, Base Hospital Kantale, ${ }^{2}$ Medical Officer, Premature Baby Unit, Colombo North Teaching Hospital, Ragama, ${ }^{3}$ Medical Officer Paediatrics, Base Hospital Thambuththegama, ${ }^{4}$ Medical Officer Paediatrics, Base Hospital Dambadeniya

*Correspondence: kashyapanetti@gmail.com

Received on 03 October 2014; Accepted after revision on 21 November 2014

The authors declare that there are no conflicts of interest

Open Access Article published under the Creative

Commons CC-BY-NC-ND Licence.
}

were more with the more educated and higher income groups. Previous use of inhalers by the patient or a family member did not significantly influence the presence of myths.

Conclusions: A significant proportion of parents / long term care-givers of children with bronchial asthma had myths and false beliefs towards starting inhaled medications. The most prevalent myth was that 'the cost of inhalers is very high'

(Key words: Parental myths, false beliefs, inhalers, bronchial asthma)

\section{Introduction}

Asthma is a common chronic childhood illness. A study done on children in the age groups 6-7 and 13 -14 years has revealed that $30-40 \%$ had wheezing at some age in their lives and $25 \%$ of them had at least one severe attack ${ }^{1}$. According to the International Study of Asthma and Allergies in Childhood (ISAAC), the prevalence rate of childhood asthma in Sri Lanka can be as high as $30-40 \%{ }^{1}$. It is also a common cause of school absenteeism ${ }^{1,2,3}$. Inhalers play a major role in the management of asthma. Sri Lankan parents entertain considerable myths and false beliefs about inhalers and as a result are reluctant to use them on their children. This leads to poor compliance of inhaled medications and negative effects on long term continuation of inhalers ${ }^{4}$.

\section{Objectives}

To assess the presence of myths and beliefs of parents / long term care providers towards starting inhaled medications in children with bronchial asthma and the influence of socio-demographic factors on them.

\section{Method}

A prospective cross-sectional descriptive study was carried out in clinics and in-ward patients of paediatric units at Base Hospital (BH) Dambadeniya, $\mathrm{BH}$ Thambuththegama and $\mathrm{BH}$ Kantale on patients who were due to be initiated or were already on inhaled medications for long term prophylaxis of asthma. A self- administered standardised questionnaire in Sinhala, English and 
Tamil was distributed among parents / long term care-givers of the study population. Those who could not understand the questionnaire were helped by one of the investigators. The sample size was calculated according to the method of S K Lwanga, and S Lemeshow ${ }^{5}$. Estimated sample size was 218. Children who presented with guardians, other than their parents, who were not long-term care providers, were not included in the study. The parents who were previously educated by our team also were not included. Results were analysed using SPSS-17. For descriptive statistics proportions, percentages and mean values were used. Different socio-demographic groups were compared using Pearson Chi-squared test.

\section{Results}

Two hundred and forty two parents / long-term care givers were enrolled in the study. Their mean age was $36.0 \quad(\mathrm{SD}=6.826)$ years. The sociodemographic data is shown in Table 1

In $88(36.4 \%)$ instances child had used inhalers before, in $151(62.4 \%)$ instances there was no prior use of inhalers by child and there were $3(1.2 \%)$ non responders. In $71(29.3 \%)$ instances a family member was using inhalers, in $161(66.6 \%)$ cases no family member was using inhalers and there were $10(4.1 \%)$ non responders. The 242 children had bronchial asthma for a median duration of 18 (Inter quartile range 10-36) months and a mean duration of 23.3 ( $\mathrm{SD}=18.8)$ months. One hundred and forty two (59.4\%) parents had already been informed about inhalers, $84.6 \%$ by a doctor, $9.1 \%$ by a nurse, $3.5 \%$ by a pharmacist and $2.8 \%$ by relatives and others.

Table 1: Socio-demographic data $(n=242)$

\begin{tabular}{|l|c|}
\hline \multicolumn{1}{|c|}{ Factor } & Number (\%) \\
\hline Relationship to child & $177(73.1)$ \\
Mother & $58(24.0)$ \\
Father & $06(02.5)$ \\
Grandmother & $01(00.4)$ \\
Non Responders & \\
\hline Ethnicity & $225(93.0)$ \\
Sinhalese & $02(0.8)$ \\
Tamil & $15(06.2)$ \\
Muslim & \\
\hline Income (Rupees) & $50(20.6)$ \\
$<30,000$ & $66(27.3)$ \\
$30-40,000$ & $53(21.9)$ \\
40-50,000 & $28(11.6)$ \\
$>50,000$ & $45(18.6)$ \\
Non Responders & \\
\hline Highest examination passed & $21(08.7)$ \\
<Grade 2 & $122(50.4)$ \\
Up to Ordinary Level & $66(27.3)$ \\
Up to Advanced Level & $17(07.0)$ \\
Up to Degree & $16(06.6\}$ \\
Non Responders &
\end{tabular}

The percentages of parents having myths/beliefs are shown in Figure 1.

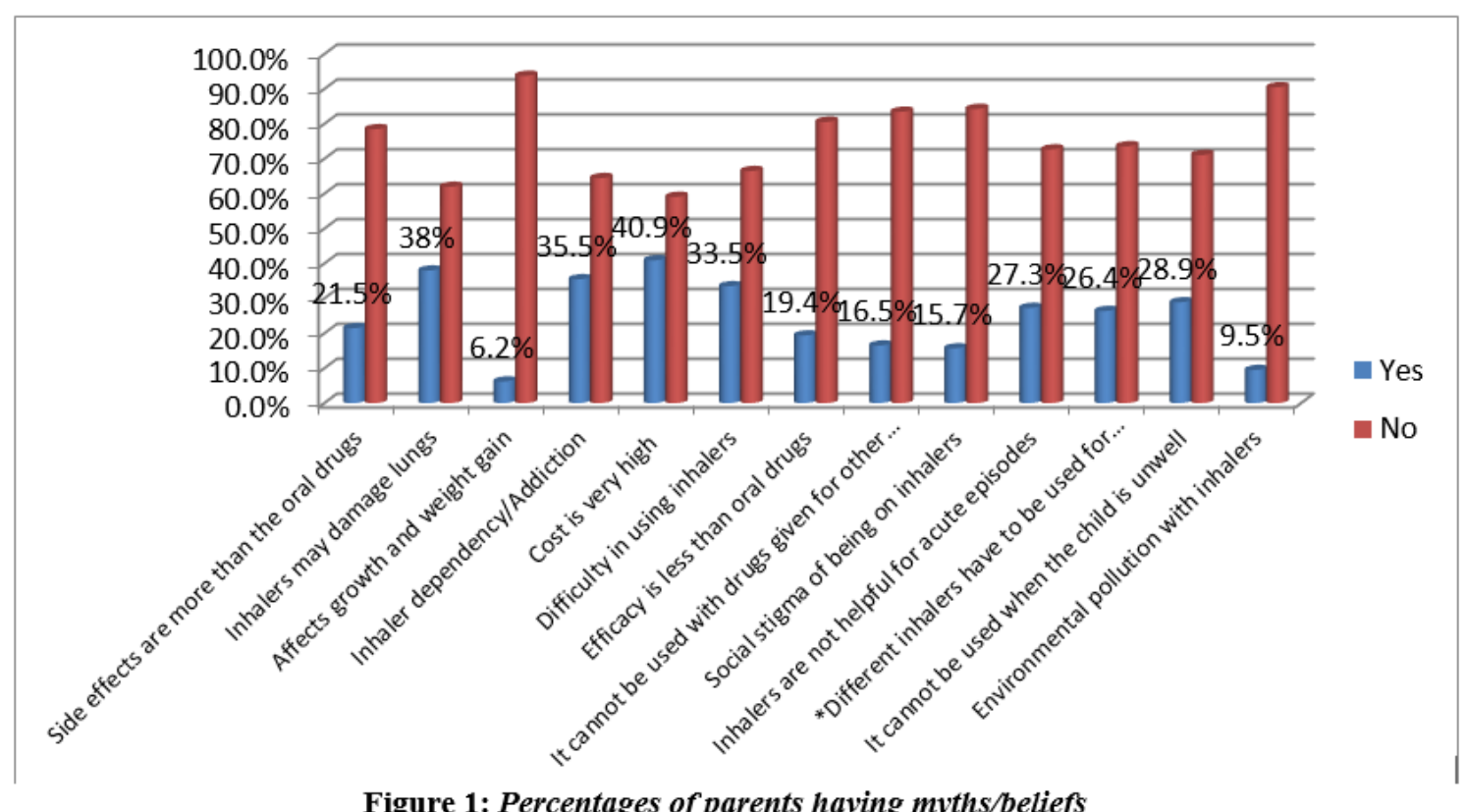

Of 222 responders, $67(30.2 \%)$ preferred oral medication to inhaled medications as long term treatment for bronchial asthma. As our objective was to identify the presence of myths and beliefs, for further statistical analysis, the response "NO" and "DO NOT KNOW" were amalgamated as 
"NO". (Both responses "No" and "Do not know" means there is no myth or belief). The associations of myths and socio-demographic factors are shown in Tables 2-5.

Table 2: Association of myths and socio-demographic factors

\begin{tabular}{|c|c|c|c|c|c|c|c|c|}
\hline \multirow{3}{*}{$\begin{array}{c}\text { Socio-demographic } \\
\text { factors }\end{array}$} & \multicolumn{8}{|c|}{ Myths } \\
\hline & \multicolumn{2}{|c|}{$\begin{array}{c}\text { Inhalers have } \\
\text { more side effects } \\
n=52\end{array}$} & \multicolumn{2}{|c|}{$\begin{array}{c}\text { Inhalers may } \\
\text { damage lungs } \\
n=92\end{array}$} & \multicolumn{2}{|c|}{$\begin{array}{c}\text { Inhaler } \\
\text { dependency } \\
n=86\end{array}$} & Cost is & y high \\
\hline & No. $(\%)$ & $\mathbf{P}$ & No. $(\%)$ & $\mathbf{P}$ & No. (\%) & $\mathbf{P}$ & No. (\%) & $\mathbf{P}$ \\
\hline $\begin{array}{l}\text { Income (Rupees) } \\
<30,000\end{array}$ & $12(24.0)$ & & $21(42.0)$ & & $19(38.0)$ & & $20(40.0)$ & \\
\hline $30-40,000$ & $08(12.1)$ & 0.021 & $17(25.8)$ & 0.011 & $19(28,8)$ & 0.373 & $30(45.5)$ & 0.364 \\
\hline $40-50,000$ & 09 (17.0) & & $18(34.0)$ & & $17(32.1)$ & & $20(37.7)$ & \\
\hline$>50,000$ & $11(39.3)$ & & $17(60.7)$ & & $13(46.4)$ & & $16(57.1)$ & \\
\hline Non Responders & $12(26.7)$ & & $19(42.2)$ & & $18(40.0)$ & & $06(13.3)$ & \\
\hline Education & & & & & & & & \\
\hline Up to grade 2 & $05(23.8)$ & & $08(38.1)$ & & 09 (42.9) & & $08(38.1)$ & \\
\hline $\mathrm{Up}$ to $\mathrm{O} / \mathrm{L}$ & $19(15.6)$ & 0.005 & $39(32.0)$ & 0.112 & $50(41.0)$ & 0.071 & $48(39.3)$ & 0.703 \\
\hline $\mathrm{Up}$ to $\mathrm{A} / \mathrm{L}$ & $16(24.2)$ & & $29(43.9)$ & & $20(30.3)$ & & $29(43.9)$ & \\
\hline Up to degree & 09 (52.9) & & $10(58.8)$ & & $02(11.8)$ & & 09 (52.9) & \\
\hline Non Responders & $03(06.7)$ & & $06(13.3)$ & & $05(11.1)$ & & $05(11.1)$ & \\
\hline $\begin{array}{l}\text { Child has been on } \\
\text { inhalers }\end{array}$ & & & & & & & & \\
\hline Yes & $22(25.0)$ & 0.292 & $33(37.5)$ & 0.970 & $24(27.3)$ & 0.052 & $39(44.3)$ & 0.426 \\
\hline No & $29(19.2)$ & & $57(37.7)$ & & $60(39.7)$ & & $59(39.1)$ & \\
\hline Non Responders & $01(02.2)$ & & $02(04.4)$ & & $02(04.4)$ & & $01(02.2)$ & \\
\hline $\begin{array}{l}\text { Family member on } \\
\text { inhalers }\end{array}$ & & & & & & & & \\
\hline Yes & $12(16.9)$ & 0.398 & $25(35.2)$ & 0.633 & $29(40.8)$ & 0.147 & $29(40.8)$ & 0.876 \\
\hline No & $35(21.7)$ & & $62(38.5)$ & & $50(31.1)$ & & $64(39.8)$ & \\
\hline Non Responders & $05(11.1)$ & & $05(11.1)$ & & $07(15.6)$ & & $06(13.3)$ & \\
\hline
\end{tabular}

Table 3: Association of myths and socio-demographic factors (continued)

\begin{tabular}{|c|c|c|c|c|c|c|}
\hline \multirow{3}{*}{$\begin{array}{c}\text { Socio-demographic } \\
\text { factors }\end{array}$} & \multicolumn{6}{|c|}{ Myths } \\
\hline & \multicolumn{2}{|c|}{$\begin{array}{c}\text { Difficulty in use } \\
n=86\end{array}$} & \multicolumn{2}{|c|}{$\begin{array}{c}\text { Efficacy is less than } \\
\text { oral medications } \\
n=47\end{array}$} & \multicolumn{2}{|c|}{$\begin{array}{l}\text { Inhalers affect growth } \\
n=15\end{array}$} \\
\hline & No. $(\%)$ & $\mathbf{P}$ & No. (\%) & $\mathbf{P}$ & No. $(\%)$ & $\mathbf{P}$ \\
\hline $\begin{array}{l}\text { Income (Rupees) } \\
<30,000 \\
30-40,000 \\
40-50,000 \\
>50,000 \\
\text { Non Responders }\end{array}$ & $\begin{array}{l}15(30.0) \\
23(34.8) \\
16(30.2) \\
10(35.7) \\
22(48.9)\end{array}$ & 0.903 & $\begin{array}{l}08(16.0) \\
10(15.2) \\
08(15.1) \\
07(25.0) \\
14(31.1)\end{array}$ & 0.657 & $\begin{array}{c}04(08.0) \\
05(07.6) \\
03(05.7) \\
0(0) \\
03(06.7)\end{array}$ & 0.493 \\
\hline $\begin{array}{l}\text { Education } \\
\mathrm{Up} \text { to grade } 2 \\
\mathrm{Up} \text { to } \mathrm{O} / \mathrm{L} \\
\mathrm{Up} \text { to } \mathrm{A} / \mathrm{L} \\
\mathrm{Up} \text { to degree } \\
\text { Non Responders }\end{array}$ & $\begin{array}{l}10(47.6) \\
41(33.6) \\
21(31.6) \\
07(41.2) \\
07(15.6)\end{array}$ & 0.541 & $\begin{array}{l}05(23.8) \\
20(16.4) \\
08(12.1) \\
07(41.2) \\
07(15.6)\end{array}$ & 0.036 & $\begin{array}{c}0(0) \\
09(07.4) \\
03(04.5) \\
02(11.8) \\
01(02.2)\end{array}$ & 0.408 \\
\hline $\begin{array}{l}\text { Child has been on } \\
\text { inhalers } \\
\text { Yes } \\
\text { No } \\
\text { Non Responders }\end{array}$ & $\begin{array}{l}25(28.4) \\
56(37.1) \\
05(11.1)\end{array}$ & 0.172 & $\begin{array}{c}22(25.0) \\
25(16.6) \\
0(0)\end{array}$ & 0.113 & $\begin{array}{c}11(12.5) \\
04(02.6) \\
0(0)\end{array}$ & 0.002 \\
\hline $\begin{array}{l}\text { Family member on } \\
\text { inhalers } \\
\text { Yes } \\
\text { No } \\
\text { Non Responders }\end{array}$ & $\begin{array}{l}27(38.0) \\
49(30.4) \\
10(22.2)\end{array}$ & 0.256 & $\begin{array}{l}14(19.7) \\
29(18.0) \\
04(08.9)\end{array}$ & 0.758 & $\begin{array}{l}06(06.0) \\
08(08.0) \\
01(02.2)\end{array}$ & 0.305 \\
\hline
\end{tabular}


Table 4: Association of myths and socio-demographic factors (continued)

\begin{tabular}{|c|c|c|c|c|c|c|}
\hline \multirow{2}{*}{$\begin{array}{c}\text { Socio-demographic } \\
\text { factors }\end{array}$} & \multicolumn{6}{|c|}{ Myths } \\
\hline & \multicolumn{2}{|c|}{$\begin{array}{l}\text { Inhalers cannot be } \\
\text { used with the drugs } \\
\text { given for other illness } \\
n=40 \\
\text { No. (\%) } \quad \text { P } \\
\end{array}$} & \multicolumn{2}{|c|}{$\begin{array}{c}\text { Social stigma of being } \\
\text { on inhalers } \\
\\
n=38 \\
\text { No. (\%) } \quad \text { P } \\
\end{array}$} & \multicolumn{2}{|c|}{$\begin{array}{l}\text { Inhalers are not helpful for } \\
\text { acute episodes } \\
\\
n=66 \\
\text { No. }(\%) \quad \text { P } \\
\end{array}$} \\
\hline $\begin{array}{l}\text { Income (Rupees) } \\
<30,000 \\
30-40,000 \\
40-50,000 \\
>50,000 \\
\text { Non Responders }\end{array}$ & $\begin{array}{l}06(12.0) \\
13(19.7) \\
06(11.3) \\
08(28.6) \\
07(15.6)\end{array}$ & 0.161 & $\begin{array}{l}05(10.0 \\
12(18.2) \\
07(13.2) \\
09(32.1) \\
05(11.1)\end{array}$ & 0.073 & $\begin{array}{l}15(30.0) \\
20(30.3) \\
11(20.8) \\
10(35.7) \\
10(22.2)\end{array}$ & 0.486 \\
\hline $\begin{array}{l}\text { Education } \\
\text { Up to grade } 2 \\
\mathrm{Up} \text { to } \mathrm{O} / \mathrm{L} \\
\mathrm{Up} \text { to } \mathrm{A} / \mathrm{L} \\
\mathrm{Up} \text { to degree } \\
\text { Non Responders }\end{array}$ & $\begin{array}{l}02(09.5) \\
25(20.5) \\
04(06.1) \\
05(29.4) \\
04(08.9)\end{array}$ & 0.022 & $\begin{array}{l}04(19.0) \\
20(16.4) \\
09(13.6) \\
03(17.6) \\
02(04.4)\end{array}$ & 0.926 & $\begin{array}{l}08(38.1) \\
30(24.6) \\
17(25.8) \\
05(29.4) \\
06(13.3)\end{array}$ & 0.622 \\
\hline $\begin{array}{l}\text { Child has been on } \\
\text { inhalers } \\
\text { Yes } \\
\text { No } \\
\text { Non Responders }\end{array}$ & $\begin{array}{l}16(18.2) \\
23(15.2) \\
01(02.2)\end{array}$ & 0.552 & $\begin{array}{c}18(20.5) \\
20(13.2) \\
0(0)\end{array}$ & 0.142 & $\begin{array}{l}33(37.5) \\
32(21.2) \\
01(02.2)\end{array}$ & 0.006 \\
\hline $\begin{array}{l}\text { Family member on } \\
\text { inhalers } \\
\text { Yes } \\
\text { No } \\
\text { Non Responders }\end{array}$ & $\begin{array}{l}17(23.9) \\
20(12.4) \\
03(06.7)\end{array}$ & 0.027 & $\begin{array}{c}13(18.3) \\
25(15.5) \\
0(0)\end{array}$ & 0.598 & $\begin{array}{l}18(25.4) \\
43(26.7) \\
05(11.1)\end{array}$ & 0.829 \\
\hline
\end{tabular}

Table 5: Association of myths and socio-demographic factors (continued)

\begin{tabular}{|c|c|c|c|c|c|c|}
\hline \multirow{3}{*}{$\begin{array}{c}\text { Socio-demographic } \\
\text { factors }\end{array}$} & \multicolumn{6}{|c|}{ Myths } \\
\hline & \multicolumn{2}{|c|}{$\begin{array}{c}\text { It cannot be used } \\
\text { when child is unwell } \\
n=70\end{array}$} & \multicolumn{2}{|c|}{$\begin{array}{c}\text { Different inhalers have to } \\
\text { be used for acute attacks } \\
\text { and for prevention } \\
n=64\end{array}$} & \multicolumn{2}{|c|}{$\begin{array}{c}\text { Environmental pollution } \\
\text { with inhalers } \\
n=23\end{array}$} \\
\hline & No. $(\%)$ & $\mathbf{P}$ & No. $(\%)$ & $\mathbf{P}$ & No. $(\%)$ & $\mathbf{P}$ \\
\hline $\begin{array}{l}\text { Income (Rupees) } \\
<30,000\end{array}$ & $16(32.0)$ & & $15(30.0)$ & & $05(10.0)$ & \\
\hline $30-40,000$ & $17(25.8)$ & 0.236 & $17(25.8)$ & 0.028 & $10(15.2)$ & 0.181 \\
\hline $40-50,000$ & $12(22.6)$ & & $07(13.2)$ & & $02(03.9)$ & \\
\hline$>50,000$ & $12(42.9)$ & & $12(42.9)$ & & $02(07.1)$ & \\
\hline Non Responders & $13(28.9)$ & & $13(28.9)$ & & $04(08.9)$ & \\
\hline $\begin{array}{l}\text { Education } \\
\text { Up to grade } 2\end{array}$ & $01(04.8)$ & & $04(19.0)$ & & $03(14.3)$ & \\
\hline $\mathrm{Up}$ to $\mathrm{O} / \mathrm{L}$ & $38(31.1)$ & 0.096 & $35(28.7)$ & 0.637 & $14(11.7)$ & 0.217 \\
\hline $\mathrm{Up}$ to $\mathrm{A} / \mathrm{L}$ & $20(30.3)$ & & $16(24.2)$ & & $04(06.1)$ & \\
\hline Up to degree & $05(29.4)$ & & $06(35.3)$ & & $0(0)$ & \\
\hline Non Responders & $06(13.3)$ & & $03(06.7)$ & & $02(04.4)$ & \\
\hline $\begin{array}{l}\text { Child has been on } \\
\text { inhalers }\end{array}$ & & & & & & \\
\hline Yes & $27(30.7)$ & 0.637 & $30(34.1)$ & 0.028 & $05(05.7)$ & 0.229 \\
\hline No & $42(27.8)$ & & $32(21.1)$ & & $18(12.1)$ & \\
\hline Non Responders & $01(02.2)$ & & $02(04.4)$ & & $0(0)$ & \\
\hline $\begin{array}{l}\text { Family member on } \\
\text { inhalers }\end{array}$ & & & & & & \\
\hline Yes & $31(43.7)$ & 0.001 & $18(25.4)$ & 0.754 & $06(8.5)$ & 0.818 \\
\hline No & $37(23.0)$ & & $44(27.3)$ & & $17(10.7)$ & \\
\hline Non Responders & $02(04.4)$ & & $02(04.4)$ & & $0(0)$ & \\
\hline
\end{tabular}


Fifty two (21.5\%) parents / long-term care givers believed that 'inhalers have more side effects than oral drugs' (Figure 1). This myth was significantly associated with the family income and the level of education of the parents / long-term care givers but not with prior use of inhalers by the child or a family member (Table 2).

Ninety two (38\%) parents / long-term care givers believed that 'inhalers may damage lungs' (Figure 1). This myth was significantly associated with the family income but not with the level of education of the parents / long-term care givers nor with prior use of inhalers by the child or a family member (Table 2).

Eighty six (35.5\%) parents / long-term care givers thought that the 'child may get addicted to the inhalers' (Figure 1). This myth was not significantly associated with the family income, the level of education of the parents / long-term care givers nor with prior use of inhalers by the child or a family member (Table 2).

Ninety nine $(40.9 \%)$ parents / long-term care givers believed that the 'inhalers were very costly compared to oral medications' (Figure 1). This myth was not significantly associated with the family income, the level of education of the parents / long-term care givers nor with prior use of inhalers by the child or a family member (Table 2).

Eighty six (33.5\%) parents / long-term care givers thought the 'use of inhalers was difficult' (Figure 1). This myth was not significantly associated with the family income, the level of education of the parents / long-term care givers nor with prior use of inhalers by the child or a family member (Table 3 ).

Forty seven (19.4\%) parents / long-term care givers believed that 'efficacy of inhalers was less compared to oral drugs' (Figure 1). This myth was significantly associated with the level of education of the parents / long-term care givers but not with family income nor with prior use of inhalers by the child or a family member (Table 3 ).

Fifteen (6.2\%) parents / long-term care givers believed that 'inhalers affect growth' (Figure 1). This myth was significantly associated with prior use of inhalers by the child but not with the family income, the level of education of the parents / longterm care givers nor with prior use of inhalers by a family member (Table 3 ).

Forty (16.5\%) parents / long-term care givers believed the myth that 'inhalers could not be used with drugs given for other illnesses' (Figure 1). This myth was significantly associated with the level of education of the parents / long-term care givers and with prior use of inhalers by a family member but not with the family income nor with prior use of inhalers by the child (Table 4).

Thirty eight (15.8\%) parents / long-term care givers believed that 'being on inhalers leads to unfavourable social stigma' (Figure 1). This myth was not significantly associated with the family income, the level of education of the parents / longterm care givers nor with prior use of inhalers by the child or a family member (Table 4).

Sixty six (27.3\%) parents / long-term care givers thought 'inhalers were not helpful for acute episodes' (Figure 1). This myth was significantly associated with prior use of inhalers by the child but not with the family income, the level of education of the parents / long-term care givers nor with prior use of inhalers by a family member (Table 4).

Seventy (28.9\%) parents / long-term care givers believed that inhalers cannot be used when child was unwell' (Figure 1). This myth was significantly associated with prior use of inhalers by a family member but not with the family income, level of education of the parents / long-term care givers nor with prior use of inhalers by the child (Table 5).

Sixty four (26.4\%) parents / long-term care givers believed that 'different inhalers have to be used for acute episodes and for prevention' (Figure 1). This myth was significantly associated with the family income and with prior use of inhalers by the child but not with the level of education of the parents / long-term care givers nor with prior use of inhalers by a family member (Table 5 ).

Twenty three $(9.5 \%)$ parents / long-term care givers believed that 'inhalers caused environmental pollution' (Figure 1). This myth was not significantly associated with the family income, the level of education of the parents / long-term care givers nor with prior use of inhalers by the child or a family member (Table 5).

\section{Age and Myths}

In this study presence of these myths according to the age was studied for 3 age groups namely less than 30 years, $30-39$ years and 40 or more years. There were no statistically significant associations.

Sex and Myths

Comparison of the presence of myths between mothers and fathers did not reveal significant difference for any of the myths studied. The most prevalent myth among the mothers was that inhalers may damage the lungs $(40 \%)$ while among the fathers the most prevalent myth was 'cost is very high' (48.8\%). 
Duration of asthma and Myths

The study population was subcategorized into 4 groups depending on the duration of asthma of their child viz. less than 12 months, 12-23 months, 24-35 months and more than 35 months. Cross tabulation showed the following statistically significant associations:

- Of 217 responders, 138 had children whose duration of asthma was less than 24 months whilst 79 had children whose duration of asthma was 24 months or more. Thirty seven of the 138 thought that 'side effects were more with inhalers than with oral drugs' compared with 12 of the 79. This was statistically significant $(\mathrm{p}=0.034 ; \mathrm{p}<0.05)$. Sixty one of the 138 thought that 'inhalers may damage the lungs' compared with 21 of the 79 . This was statistically significant $(\mathrm{p}=0.007$; $\mathrm{p}<0.01)$.

- Of 217 responders, 184 had children whose duration of asthma was less than 36 months whilst 33 had children whose duration of asthma was 36 months or more. Seventy three of the 184 believed in inhaler dependency / addiction compared with 4 of the 33 . This was statistically significant $(\mathrm{p}=0.001 ; \mathrm{p}<0.01)$.

- $\quad$ Of 217 responders, 93 had children whose duration of asthma was less than 12 months whilst 124 had children whose duration of asthma was 12 months or more. Eighteen of the 93 thought that 'different inhalers have to be used for acute attacks and for prevention' compared with 39 of the 124 . This was statistically significant $(\mathrm{p}=0.031 ; \mathrm{p}<0.05)$. Seventeen of the 93 thought that 'inhalers cannot be used when the child is unwell' compared with 42 of the 124 . This was statistically significant $(\mathrm{p}=0.008 ; \mathrm{p}<0.01)$.

\section{Discussion}

In the management of any chronic illness, compliance is a major requirement. Noncompliance with inhaled prophylactic medication has been estimated to be 30 to $50 \%$ in children ${ }^{6,7}$. Treatment of childhood asthma has become a more complex process as significant proportion of parents have myths and unscientific beliefs ${ }^{8,9}$. Thus, parents who doubt the efficacy of inhalers and have misconceptions and myths regarding the use of inhalers are less likely to enforce treatment adherence diligently in their child and hence the compliance would be poor in them ${ }^{8,9}$. Therefore, education and counselling of the parents of patients are important in ensuring compliance ${ }^{10}$. In that context, it is important to identify the common myths and beliefs in our parents and their associations with socio-demographic factors. Future programmes on education and counselling have to be planned by taking into account these myths and false beliefs.

In this study, our plan was to identify common myths and beliefs and their prevalence. Majority $(73 \%)$ of the long-term caregivers who accompanied these patients were mothers. Due to the variation of the distribution of ethnic groups in Dambadeniya and Thambuththegama, 93\% of enrolled patients were Sinhalese. This does not represent the true national ethnic proportions. More than $75 \%$ of families had incomes exceeding Rs.30,000 and more than $75 \%$ had education up to GCE (Ordinary Level) or higher and 98\% had education above Grade 5. Therefore, this study population had reasonable incomes and good levels of education. Around $60 \%$ of this population already had information regarding the use of inhalers and of them, more than 95\% had been counselled by a health care worker.

The most prevalent myth or false belief among our parents / long-term caregivers was that 'the cost of inhalers is very high' $(41 \%, n=99)$. Among the other myths, 38\% believed that 'inhalers may damage the lungs', $36 \%$ believed in 'addiction to inhalers or dependency' and $34 \%$ in 'difficulty in using inhalers'. A study done in Malaysia showed that $91 \%$ of parents were concerned about side effects of inhalers, $86 \%$ thought of inhaler addiction, 34\% were concerned with the cost and $15 \%$ were concerned about the difficulty in using inhalers ${ }^{8}$. Compared to Malaysian parents the presence of those myths in our population is significantly less. Although Malaysian parents were more concerned about side effects, our parents' main concern was the cost. This concern can be addressed by making those different types of inhalers and spacer devices freely available at the state sector hospitals.

Percentage of parents / long-term caregivers believing 'inhalers have more side effects' $(p=0.005)$, 'efficacy is less than oral drugs' $(p=0.036)$, and 'inhalers cannot be used with the drugs given for other illnesses' $(p=0.022)$ were significantly associated with their levels of education. This needs further study. In the Malaysian study population there was no significant association noted with education ${ }^{8}$. Contrary to expectation, the myths that inhalers are not helpful for acute episodes' $(\mathrm{p}=0.006)$ and 'inhalers affect growth; $(p=0.002)$ were significantly more in parents whose children had been on inhalers. There was no significant impact 
of having another family member on inhalers on the presence of these myths and beliefs.

The false beliefs that 'side effects were more with inhalers than with oral drugs' and 'inhalers may damage the lungs' were significantly less in parents / long-term care givers whose children had a duration of asthma of 24 months or more. Significantly less number of parents / long-term care givers whose children had a duration of asthma more than 35 months believed in 'inhaler dependency / addiction'. However, the myth that 'different inhalers have to be used for acute attacks and for prevention' was significantly more among the parents / long-term care givers of the 12 month or more group compared to the less than 12 month group.

\section{Conclusions}

- A significant proportion of parents / longterm care givers of children with bronchial asthma have myths and false beliefs.

- The most prevalent myth or false belief among our parents / long-term caregivers was that 'the cost of inhalers is very high'

\section{Recommendations}

Health education programmes should go in handin-hand with the prescription of asthma inhalers to correct these myths and false beliefs and hence achieve maximum benefit of these inhalers by improving compliance. It would be advisable to use leaflets and multimedia to educate parents accompanying these asthmatic patients, in addition to verbal advice for a better outcome.

\section{Acknowledgements}

We thank Dr B J C Perera, Consultant Paediatrician for invaluable support and guidance provided, Dr Suneth Agampodi, Consultant Community Physician and Senior lecturer in Community Medicine, Rajarata University and Dr Suranga Fernando Senior Registrar in Community Medicine for advice and guidance on statistical analysis, all the staff of these hospitals for their kind cooperation and all the parents who participated in this research project, for their support.

\section{References}

1. SLMA Guidelines on the Management of Asthma 3rd ed. Expert Committee on Asthma. Colombo: Sri Lanka Medical Association; 2005.
2. Doull IJ, Williams AA, Freezer NJ, Holgate ST. Descriptive study of cough, wheeze and school absence in childhood. Thorax 1996; 51(6): 630-1.

http://dx.doi.org/10.1136/thx.51.6.630

PMid: 8693448 PMCID: PMC 1090497

3. British Guideline on the Management of Asthma - a national clinical guidelineMay 2008. Available from:

http://www.guidelines.gov/content.aspx?id $=15073$

4. Conn KM, Halterman JS, Lynch K, et al. The impact of parents' medication beliefs on asthma management. Pediatrics 2007; 120 (3): e521-6.

http://dx.doi.org/10.1542/peds.2006-3023

PMID: 17766496 PMCID: PMC4335716

5. Lwanga SK, Lemeshow S. Sample size determination in health studies: A practical manual, Geneva, WHO; 1991. PMCID: PMC2393240

6. Milgroin $\mathrm{H}$, Bender $\mathrm{B}$, Ackerson L, Bowry P, Smith B, Rand C. Noncompliance and treatment failure in children with asthma. Journal of Allergy and Clinical Immunology 1996; 98: 105-7.

7. Coutts JAP, Gibson NA, Paton JY. Measuring compliance with inhaled medication in asthma. Archives of Disease in Childhood 1991; 67:332-3. http://dx.doi.org/10.1136/adc.67.3.332

8. Chan PW, DeBruyne JA. Parental concern towards the use of inhaled therapy in children with chronic asthma. Pediatric International: official Journal of the Japan Pediatric Society 2000; 42(5):54751.

http://dx.doi.org/10.1046/j.1442200x.2000 .01278.x

9. Lim SH, Goh Dyt, Tan Ays, Lee BW. Parents' perceptions towards their child's use of inhaled medications for asthma therapy. Journal of Paediatrics \& Child Health 1996; 32(4):306-9.

http://dx.doi.org/10.1111/j.14401754.1996 .tb02559.x

10. Becker MH, Maiman LA. Strategies for enhancing patient compliance. Journal of Community Health 1980; 6:113-15. http://dx.doi.org/10.1111/j.14401754.1996 .tb02559.x 